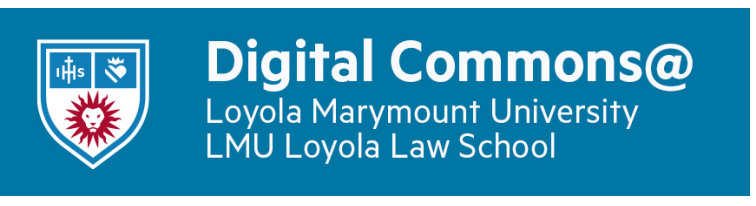

Journal of Catholic Education

Volume 6 | Issue 1

Article 6

9-1-2002

\title{
What Does It Mean to Be Human? Education for World Citizenship
}

Alan T. Wood

Follow this and additional works at: https://digitalcommons.Imu.edu/ce

\section{Recommended Citation}

Wood, A. T. (2002). What Does It Mean to Be Human? Education for World Citizenship. Journal of Catholic Education, 6 (1). http://dx.doi.org/10.15365/joce.0601062013

This Article is brought to you for free with open access by the School of Education at Digital Commons at Loyola Marymount University and Loyola Law School. It has been accepted for publication in Journal of Catholic Education by the journal's editorial board and has been published on the web by an authorized administrator of Digital Commons at Loyola Marymount University and Loyola Law School. For more information about Digital Commons, please contact digitalcommons@lmu.edu. To contact the editorial board of Journal of Catholic Education, please email JCE@nd.edu. 


\section{WHAT DOES IT MEAN TO BE HUMAN? EDUCATION FOR WORLD CITIZENSHIP}

\section{ALAN T. WOOD}

University of Washington, Bothell

What is the purpose of education in a democracy? What is the meaning of freedom? These questions are explored in depth in this essay as the author attempts to expand the conversation between private and public education. Without reference to religious purposes or Gospel mandates, the article explores possible responses to ultimate questions of meaning by mining language, history, biology, and technology for answers.

Ta $\mathrm{n}$ an effort to contribute to ongoing dialogue between Catholic education and the public sector, this article seeks to present relevant scholarship outside the domain of Catholic education but clearly connected to it and its purposes. Thanks to John Goodlad of the Institute for Educational Inquiry for his assistance with this effort.

\section{HISTORICAL INTRODUCTION}

Let me start with a general proposition, namely that the fundamental purpose of education is to prepare students to participate in a democratic world with compassion, responsibility, and wisdom. I endorse that proposition. It complements but does not deny the more conventional view that the purpose of education is to prepare students for the workforce. That latter interpretation is not necessarily wrong. On the other hand, it is not entirely right. To be sure, preparing students for a lifetime of productive work is a worthwhile outcome of schooling, but there is more to schooling than vocational training, and there is more to education than schooling.

To claim that the primary object of schooling is to prepare students for a job is to forget that even the existence of a job depends on a host of enabling circumstances. The overall health of our schools and even our economy depends on the larger context of three essential prerequisites: democracy on the national level, peace on the international level, and environmental well- 
being on all levels. To focus exclusively on the narrative of economic utility (Postman, 1995) while ignoring the larger perspective of the nation and the world, is about as farsighted as rearranging deck chairs on a sinking Titanic.

The first prerequisite is democracy. The notion that the proper role of education is to prepare students for democracy has a long and distinguished pedigree from Dewey to Goodlad. From the time Dewey taught at the University of Chicago in the 1890 s, he argued that democracy was not a faroff goal, but a process emanating from a fundamental impulse in the human personality to be free (Dewey, 1899). As a process rather than an outcome, it deserved to be incorporated into all aspects of education as well as politics. That vision has remained relevant and true for the past century. If there is anything different about the nature of the world from the time Dewey began his career until now, it is in the magnitude of the change that has taken place in the two other arenas essential for the health of the educational process: a peaceful world and a sustainable environment. A century ago the ascendancy of the West, and therefore of the United States as well, in world politics was assumed. On the global stage, the West was the dominant force. It ruled the world. Among the Western powers, the United States occupied a unique status. It was distant enough from Europe to avoid its entangling alliances but strong enough to retain its own independence of action. As a result, it could and did remain aloof from involvement in world affairs. Only in midcentury, during and after the Second World War, did the United States assume a role of world leadership commensurate with its power and prosperity (Keylor, 1996).

This new role was part of a major shift in global power from Europe to the United States and the Soviet Union. The Cold War and the new capacity of the Soviet Union to launch missiles that could strike American targets within minutes effectively removed the shell of invulnerability with which Americans had once surrounded themselves. Throughout this period, however, the West still remained at the top of the global food chain. We lived in a bipolar world, but both poles were Western. The rest of the world, with a few significant exceptions, was compelled to declare allegiance to one pole or the other.

\section{CURRENT SITUATION}

In the early 1990s, this alignment suddenly changed. The collapse of the Soviet Union had the effect of releasing nationalist forces from the cage into which they had been thrown by the superpowers during the Cold War. Conflicts in the Balkans and in Central Asia that might once have been kept in check erupted into violence, threatening the peace and stability of the entire region. In addition, the spectacular growth of the economies of East and Southeast Asia could no longer be ignored. The comparative advantage 
that had been enjoyed by European and American economies since the 19th century began to erode as the industrial revolution moved to Asia. For the first time in two centuries the ascendancy of the West could no longer be assumed. Along with these momentous changes came a new awareness of the environmental degradation produced by wholesale industrialization around the world in the last century or so. Beginning with the publication of Silent Spring by Carson in 1962, the environmental movement became more prominent in the public consciousness in proportion as the concern over the Soviet threat receded.

Given the urgency of these three developments in the 20th centurynationalism, a multipolar world, and environmental degradation-we need to ask ourselves if the role of education should not adapt accordingly. Is it enough to focus on the democracy of our own nation, as it was reasonable to do in the past when we could assume there were no external threats to our nation and when the United States did not play such a crucial leadership role? Should we not elevate our perspective to include the world as a whole to prepare our young people for global citizenship, as Dewey and Goodlad have argued so persuasively that we should prepare them for democratic citizenship? Goodlad himself has already pointed the way to a more global scale of application of the democratic process. More than 20 years ago he wrote, "understanding oneself is not enough. One must transcend self to become aware of and to understand all people and their institutions, all nations and relations, all cultures and civilizations-past, present, and future" (Goodlad, 1979, p. 49). Now, as never before in human history, the world sinks or swims together, and the stakes are nothing less than our survival as a species on this earth. Given the present predicament of the world, we would do well to heed H. G. Wells' warning that civilization is a race between education and catastrophe.

I am aware that the term "world (or global) citizenship" is not a masterpiece of clarity. For many politicians it is easily converted into some platitude or other about students taking their place in a global economy. All platitudes, of course, contain a kernel of truth. However, as an idea that would be capable of inspiring educators to effective renewal of our educational institutions, it is inadequate to the task. A program of educational renewal capable of generating a realistic possibility of succeeding has to be based on some fundamental truth of the human condition above and beyond mere economic self-interest.

There is more to the human potential than the capacity to produce, important though that may be. Human beings also have the potential to love, to create, to seek truth, and to play, among many other activities. Education for democracy is not just about politics but about realizing the full spectrum of the human potential through the exercise of freedom. As Goodlad (1997) put it: 
The theme most central to the drama of history is the struggle of human beings for choice in their development of temporal wisdom and spiritual belief, whether the medium be novel, poem, play, painting, or song. It is a theme that transcends all the rich variations in humankind: a struggle for freedom of thought and expression, of access to knowledge, of belief, and to pray. (p. 2)

Education for global democracy, or global citizenship, therefore rests upon an assumption that the aspiration for freedom is universal to all human experience-regardless of cultural heritage-and constitutes one of the most ennobling qualities of our humanity. By preparing students to work toward a world of democracy we are serving the deepest impulses of our humanity and theirs. Should we not put the task of serving democracy in global terms, where the quest for freedom will have enormous consequences for our own democracy? In the long run, we can prosper only in a global association of other democracies at peace with each other and working in harmony with the environment.

We have much reason for optimism. On the level of the nation-state, the aspiration for freedom became a reality for many countries in the 20th century. At the beginning of that century, there were only half a dozen nations in the world that could be called democratic in any reasonable sense of the word (out of a total of about 43 independent nation-states at the time). Most of the ensuing century was then taken up with a long struggle between totalitarian and democratic governments that lasted through two World Wars and the Cold War. Until very recently, the outcome of this struggle was not at all clear. Even by 1980 , only 37 of the then 121 countries in existence qualified as democratic. By the year 2000, however, out of a total of 193 independent countries, fully 117 are democratic, containing roughly $54 \%$ of the world's population (Emmott, 1999, p. 7). That statistic represents an extraordinary success. Much remains to be done, of course. Major portions of the world are still governed by authoritarian rulers, and even in budding democracies such as Russia the institutional foundations for democracy are only beginning to be laid. Nevertheless, the trend would seem to suggest that democracy is becoming the norm in the world rather than the exception.

\section{FREEDOM AS ESSENTIAL}

Freedom, once gained, however, is only the beginning. After achieving freedom, many countries were then faced with the formidable challenge of deciding what to do with it. Was freedom simply a matter of every individual doing what he or she wanted? Was the primary purpose of freedom to produce more goods so we could consume more? We in the United States have not been exempt from this introspective exercise. After the collapse of our former 
adversary, the Soviet Union, our sense of common purpose appears to have evaporated. In the absence of any consensus about the direction of the country as a whole, we have resorted to a fallback position, which often seems to resemble little more than a commitment to wholesale self-indulgence. As all successful temptations do, this commitment comes wrapped in the mantle of one of our own most cherished virtues, namely individualism.

The doctrine of individual freedom forms the bedrock of modern American life. For Americans, the word "freedom" is surrounded by an aura of legitimacy that is almost religious in inspiration, but it is freedom of a particular kind, usually defined as whatever the individual - taken to be a morally autonomous being - wants to do. No reference to a higher moral authority is necessary or even appropriate because there are no longer assumed to be moral universals that transcend the individual will. According to this definition, authority is the natural adversary of freedom because it places limits on those freedoms. The assertion that freedom stands in a naturally antithetical relationship with authority has a long and distinguished pedigree stretching back to the Enlightenment and beyond. It is not difficult to see why freedom and authority came to be seen as enemies. In the 18th century revolutionary intellectuals who believed in the emerging doctrine of popular sovereignty found themselves increasingly opposed by monarchs unwilling to surrender power. The American War of Independence and the French Revolution were the first political manifestations of that struggle. By the 19th century it became common to define freedom primarily as an absence of constraint, particularly the kind of constraint imposed by repressive governments. Expressing the climate of his age, Mill (1961) wrote on the very first page of his essay "On Liberty" that "the struggle between liberty and authority is the most conspicuous feature in ... history" (p. 249).

Intellectuals wanted freedom; those in authority resisted giving it to them. Understandably, idealistic intellectuals concluded that authority was the enemy of freedom. Their view has, over the centuries, percolated down into everyday culture. Even the average American teenager, though not generally an expert on the French Enlightenment, nevertheless manages by some miracle of osmosis to convey the essence of 18 th-century views on the relationship between freedom and authority whenever called upon to justify a particular course of action. In the typical conversation between parents and teenagers over some major philosophical issue such as what time to be at home on a given Friday night, the teenager is fully capable of collapsing eight centuries of political thought into one or two cogent sentences that usually make the following point: he or she is a morally autonomous individual-and therefore free-over whom the average parental unit has no authority.

I know. I was a teenager once myself, and remember raising those very arguments. Then, by a process that can only be described as divine justice, I became a parent of teenagers myself. At the same time, I was also teaching 
undergraduate survey classes in Western and world history that chronicled the rise of individualism in modern Europe. It gradually dawned on me that there might be a connection between the individualism manifested by my teenagers and the subjects I found myself teaching in the classroom. I wondered whether both nation-states and teenagers did not tend to be motivated more by the pursuit of individual interests than by a desire to serve the common good.

\section{THE MEANING OF EXISTENCE}

Like any red-blooded academic baffled by an intractable problem, I decided to write a book about it (Wood, 2001). The more I thrashed around trying to make sense of it all, the more I kept coming back to a philosophical problem in the definition of freedom. Most people, following the lead of the Enlightenment thinkers, continue to take freedom to mean primarily an absence of constraint. Certainly that is the dominant understanding among economists who focus on the marketplace. From their perspective, the astonishing success of competitive capitalism seems to confirm their understanding of freedom. True, the forces of capitalism have stimulated a massive increase in worldwide productivity in the past few decades. One cannot help wondering, however, if naked self-interest unrestrained by any reference to the common good does not ultimately threaten the moral and social foundations of human community. Like it or not, life in a community frequently requires the individual to subsume self-interest in a larger cause or to redefine self-interest in a manner that incorporates communal as well as individual goals.

One avenue of exploring this problem was to invoke the religious and philosophical heritages of non-Western as well as Western cultures. In some ways this path was natural for me, since my academic field is Chinese history. In many non-Western (as well as Western) traditions, the fulfillment of self (i.e., human freedom) emanated not from the pursuit of self-interest but from the transcendence of self-interest. In most cases, however, those views were rooted in an assumption about the centrality of religious faith or moral truth to a full understanding of the human potential. Such an argument would make no sense to the vast majority of intellectuals in the United States and Europe, most of whom are secular in their loyalties or who, if religious, believe religion to be a matter of private belief with little relevance to the great public issues of the day.

So I turned my attention to a more secular explanation. In doing so, I considered myself in good company. Even Smith was preoccupied with this problem. His Theory of Moral Sentiments was an inquiry into the necessity of placing moral limits on human greed (Smith, 1976). Nor was Smith alone in this concern. Burke shared Smith's reservations about the limitations of 
human motives when he wrote that "men are qualified for civil liberties in direct proportion to their capacity to place moral chains upon their appetites. Their passions forge their fetters" (Burke, 1803, p. 4). Clearly they believed that the fruits of human freedom were obtainable only through the exercise of self-discipline. The problem was that they lived in a time when the need for a moral foundation of human behavior was taken for granted. There may have been plenty of hypocrisy around, but if one takes hypocrisy as the tribute vice pays to virtue, then at least there was an acknowledgment that virtue existed.

That assumption is no longer shared by most intellectuals, so I considered the possibility that the crux of the problem might be in our understanding of freedom itself. Freedom has long been regarded as one of the distinguishing qualities of Western civilization. Patterson refers to it as "the core value of Western culture throughout its history" (1991, p. xiii). In the field of world history, the doctrine of the progress of freedom was the integrating principle of the great synthesizing histories of the 19th century. Hegel's (1956) statement that "the history of the world is none other than the progress of the consciousness of freedom" (p. 19) is often quoted as the quintessential formulation of that principle. This faith in the progress of freedom did not last very far into the 20th century. It was dashed to pieces by the revelations of the terrible destructive potential of ideology and technology that burst upon Europe in the years between 1914-1945. Instead of progress, we seemed to have taken a giant step backward to primitive savagery on a scale scarcely imaginable to the human mind and heart.

The despair into which this spectacle of human evil thrust the secular intellectuals of the 20th century was profound and lasting. It gave rise to existentialism and other schools of postmodern thought that place the burden of finding any meaning in existence entirely with the individual (and, naturally, autonomous) human mind. Underlying all these worldviews is a continuation of the assumption that freedom is defined as an absence of constraint. As I tried to sort all this out, it seemed to me that I would have to build my case from the ground up, starting by justifying a different understanding of freedom. To do that required me to look at the whole of human experience in a way that most of my colleagues in the American academy who share a mechanistic understanding of the world, focusing on small nuggets of knowledge, would question. Nevertheless, I was convinced that only by looking at the larger context of the world as a whole would we be able to see the problem from a fresh perspective. So I began to toy with the proposition that human freedom is not the consequence of an absence of constraint, and that history is not the record of pushing outward the boundaries of constraint but that, on the contrary, freedom is defined by constraints and that history is a record of shifting the location of those constraints. More to the point, without constraint freedom would cease to have any meaning whatsoever. As I looked for illustrations of this interpretation, I began to see them everywhere. One of the best is language itself. 


\section{LANGUAGE, BIOLOGY, AND TECHNOLOGY}

The development of language, which appears to have taken place among the earliest members of modern Homo sapiens, was one of the great milestones of human freedom. The feast of choices available to humankind was enriched beyond measure after language enabled humans to communicate complex knowledge and feelings from person to person and from generation to generation. Language made it possible to share experience and thus to cooperate on a level never before realized. Language facilitated a whole new dimension of rational thought as well as a new tool of individual and communal identity. Expanding or eliminating constraints, moreover, did not achieve these new freedoms. On the contrary, language is one of the most structured, rule-based activities in which humans participate. It is these very rules that make language possible. Any one individual could decide to break all the rules, that is, abandon all constraints of grammar and vocabulary in the name of freedom, but if other people did not understand the resulting random utterances, then the whole purpose of language-to communicate-would cease to exist. Rules are therefore the "author" of the freedom made possible by language; in other words "authority" and freedom are inextricably linked to each other. To take the reverse perspective, without the freedom to be creative within the context of the rules of language (or authority), then language would be just as meaningless as it would be if there were no rules. The relationship between freedom and authority is as complementary and mutually dependent as the yin and the yang. My view of history, and by extension of the world around us, is that this same relationship prevails in all of our most important human activities.

The relationship actually begins in the very structure of the natural and biological world in which we live. Even at the most basic cellular organization of all forms of organic life, where the information for protein synthesis and replication is accomplished, structure is the author of freedom. The makeup of the DNA molecule (deoxyribonucleic acid) located in the nucleus of every cell has carried the information necessary for the sustenance and perpetuation of life since the beginning of life on the planet. The exceedingly complex architecture of the molecule, with its combination of two strands of genetic material in the form of a spiral staircase known as the double helix, makes a vast array of choices possible. Freedom, in the form of the ensuing mutations, is thus incorporated into what otherwise might have been a closed mechanism capable only of replicating an exact version of the parent. Without that possibility of choice, or freedom, the full richness of organic life on earth would never have been possible. Indeed, the actual number of possibilities is stunning: $4 \times 10^{400,000,000}$, to be exact (and more by a huge amount even than the total number of elementary particles in the known universe). On the other hand, the structure is sufficiently rigid and uncompromising that only a tiny fraction of the mutations produced by this process-namely those which 
enable the organism to adapt more readily to the environment around it-can survive and flourish. The rest perish.

The same lessons are apparent in the arena of technology. From the earliest triumphs of technology, such as the mastery of fire, down to the latest breakthroughs in genetic engineering, humankind has had to confront a fundamental dilemma. Every step forward in opportunity has been matched by a step backward in danger. Take an advance in technology as simple and momentous as fire. Just as fire benefited people by cooking meat, providing light in the darkness and heat in the winter, and frightening wild animals, so it also harmed people by destroying their homes, their habitat, and sometimes their lives. To harness its potential for good while avoiding its potential for harm required discipline and cooperation. The acquisition of fire, in other words, enhanced human freedom but only insofar as it simultaneously imposed new responsibilities on human behavior. One could not exist without the other.

This relationship even holds true for purely human contrivances such as clocks. The impact on human history of inventing a mechanical device to measure accurately the passage of time has been widely studied. What is less widely noted is the manner in which such machines, built and operated according to strict laws of nature and culture, contribute to human freedom in both ancient and modern times. Even as early as the agricultural revolution, accurate understanding of time enabled farmers to sow their crops at the appropriate time in the spring. The surplus of food produced by a prosperous agricultural sector then made possible the rise of cities and all the arts of civilization that followed. This magic phenomenon, by which the doorway to human freedom is framed by the bricks of natural laws, is also illustrated by specific technological breakthroughs such as the invention of the chronometer by John Harrison in the 18th century. Through this device navigators at sea were finally able to fix their precise location, freeing them from the anxieties of shipwreck and simultaneously opening up the world to a reliable and safe system of maritime commerce (Sobel, 1995). A more accurate rendering of the inflexible and inexorable passage of time, in other words, opened the door to a new vista of freedom and opportunity. These new freedoms, moreover, came not by eliminating constraints but by using them to new purposes.

In a similar vein, scientists in more recent times learned how to tap the fundamental power of the universe - the atom-not by eliminating constraints but by exploiting them. They did not invent the laws of nature. They merely harnessed them to human purposes. Once again, nature was the author of human freedom. Just as with the appropriation of the technology of fire, nuclear energy has been used for both benefit and harm. By providing an alternative source of energy and a new means of treating the sick, nuclear power has widened the scope of human opportunity. On the other hand, by 
making possible a new class of weapons of mass destruction, nuclear energy has raised the specter of Armageddon in our time. Never in the history of our species has the responsibility of using our knowledge and power wisely been more essential, even as we are now more "free" than ever before. No area of human knowledge expresses more forcefully the relationship between freedom and responsibility than that of nuclear energy. Given the awesome destructive power that now resides in our own hands, the claim that human freedom can be fully understood as an absence of constraint becomes difficult to sustain. The advance of human freedom does not eliminate constraints; it merely shifts their location. The greater the freedom, the greater the responsibility imposed by those constraints.

\section{LESSONS FROM HISTORY}

In the realm of economics, the dynamic relationship between freedom and authority also endures. Even in the transition from hunting and gathering societies to settled agricultural communities, new freedoms were accompanied by a new assortment of limitations and responsibilities. Constraints did not disappear; they merely changed. In hunting and gathering societies, the production and distribution of scarce resources were relatively simple. People lived in communities of about 30-50 members. Possessing only portable property, they went where the food was. They appear to have had a balanced diet, and to have spent only about an average of 20 hours a week foraging for food, leaving the remaining time for leisure activities of a kind we can only guess at but which must have involved an intense level of human communication. Hierarchy seems to have been at a minimum and everybody shared equally in the fortunes and misfortunes of the community as a whole.

When we fast-forward to the next stage of social and economic development, namely agricultural communities, the picture changes drastically. The density of population increased exponentially because agriculture was able to produce a much greater abundance of food than before. This population, moreover, was now settled in one place. Communities that generated a surplus of food were able to free up individuals to work as artisans, making possible specialization in arts and crafts. There was a price, however. By basing their sustenance on a narrow range of cultivated crops, these communities were much more vulnerable to plant diseases or weather changes than they were before. Living in greater numbers, they were also more vulnerable to diseases carried by fellow humans and by animals. Their constraints did not disappear, in other words - they merely changed (Fagan, 1995).

With settled communities came the necessity of politics and law. In our time the relationship between a rule of law and the freedoms that we have come to associate with democracy are so clear as almost to be not worth mentioning. We are fully accustomed to understanding the authority of law as the 
protector of freedom. Less well understood is the manner in which the three main political institutions developed by our ancestors-the state, the empire, and the nation-state-are themselves a manifestation of this same complementarity of human freedom and authority. In all cases an excess of one at the expense of the other resulted in catastrophe. Too much freedom led to anarchy; too much authority led to tyranny or stagnation. When they reinforced each other, the outcome was a highly durable society. Imperial Rome and classical China are expressions of this process at work. The Romans, supreme geniuses in public administration, developed one of the most successful institutional expressions of a balance between human freedom and legal authority in human history. Confronted by an empire of considerable diversity in customs and languages, the Romans created a three-tiered platform of laws capable of balancing local and Roman systems of jurisprudence. Local disputes were settled according to local laws, known as ius gentium, or the law of nations. Disputes involving Roman citizens were settled according to Roman law, known as ius civile. Above both of these there came to be acknowledged a universal standard of justice known as natural law, or ius naturale, which transcended the civil and national laws of individual societies and reflected a higher truth about the human condition (Stein, 1999).

The Chinese empire, faced as well with the challenge of ruling over a vast territory composed of a wide variety of ethnic traditions, followed a similar path of balancing local freedoms with central authority but in an entirely different way. Throughout Chinese history there never developed a centralized code of civil law. Local communities decided civil disputes on the basis of local customs and traditions. Criminal law remained within the purview of the state, but even there wide latitude was given to local communities to deal with transgressors. Over those systems of applied law there operated a structure of moral authority, based on Confucian texts widely circulated and read by all the educated leaders of the country, that was understood to be universal and to which all the local leadership of China pledged their loyalty (Hucker, 1975). The Chinese tradition may not have been democratic in the manner of the modern West, but it certainly valued human freedom, without which moral action itself would be impossible.

Even in bureaucracy - the handmaiden of civilization - the same complementary relationship between freedom and authority manifests itself. Bureaucracy grew out of a very specific need in the early development of cities and the state throughout the world. As the unit of human cooperation grew beyond the level of the hunter-gatherer, the organizational challenges of the community enlarged accordingly. Those communities that began to specialize developed greater proficiency in critical areas such as food distribution and defense than other communities, enhancing their chances at survival. But the new class of specialists had to be managed in such a way that their energies could be utilized most efficiently. In time, they required either 
money or some other kind of remuneration, which necessitated taxation. Collecting and recording those taxes, in turn, required organizational rules and procedures that gradually developed into what we now call bureaucracy. As cumbersome and annoying as those new rules and procedures were to those compelled to abide by them (recalling Weber's characterization of bureaucracy as an "iron cage"), they nevertheless made possible an entirely new cornucopia of freedoms and opportunities to human civilization (Weber, 1958).

In a similar vein, cities for thousands of years have been magnets for the most creative and imaginative individuals of almost every society on earth. The bigger the city, the greater the magnetic power. Yet the vibrant life of the city rests upon a foundation of ordered rules and procedures that are mindboggling in scope. We take those rules entirely for granted until we visit cities where they either do not exist or are not obeyed. One has only to observe the chaos into which Russian cities-or indeed the entire nation-have descended after the collapse of the Soviet Union to see this process manifested in all its destructive potential. When one considers the potential of the Russian people, their high level of education, their advanced system of transportation and communication, and their generally developed economy, their current paralysis is doubly hard to explain. Only by reference to the relationship between freedom and authority can one fully comprehend what has happened. In the name of freedom the Russians abandoned the institutions of the past, but failed to replace them with new institutions (i.e., authority) capable of organizing the energies of citizens in such a way that the needs of the community and those of the individual were in reasonable balance with each other.

One of the lessons of history that is repeated over and over again, from culture to culture and from one period to the next, is the importance of adapting human institutions to respond to changing circumstances. The primary purpose of institutions is to solve problems. Too often the problems change but the institutions do not. That happens so often, in fact, as almost to constitute the normal state of affairs in most societies. In those cases authority suffocates freedom rather than enhancing it. Certainly that was the case in the former Soviet Union. The important lesson to draw is not that the crisis arises from authority itself but from an abuse of authority stemming from its lack of balance with freedom. The great challenge for any society is to renew its institutions constantly so that they respond to the always changing nature of the problems in a manner that fully respects the deep human need for freedom. Most societies, most of the time, fail to reach such a balance because institutions are so inherently resistant to change.

In rare instances in human history all the institutions of a community reinforced each other in such a way that the human talent within its care was enabled to reach new heights of achievement. Classical Athens in the 5th century B.C. was certainly one such instance, as were Tang and Song China and 
Renaissance Europe. These periods of cultural brilliance were grounded in freedom, expressing a wide diversity of views. People in classical Athens certainly did not think alike - the place was a bubbling cauldron of competing doctrines. But there was an atmosphere of confidence in human powers that is breathtaking, along with a profound recognition of human limitations. Such moments were usually not lasting. The balance was too fragile. But when they happened they were truly astonishing (Treadgold, 1990).

What the ancient Greeks and the classical Chinese applied to their own society we must now apply to the world at large. Global citizenship requires future generations, composed of children we are now educating (and their children), to see the world as a whole, in all its manifest connectedness. They need to understand that the freedoms we so cherish in our lives depend on a world composed of healthy democracies living in peace with each other and in an environment of sustainable agriculture and industry. The opportunities thus created, moreover, come about not by eliminating constraints, but by accepting them wholeheartedly. The challenge is to create structures of authority that maximize freedom. The European Union (EU) represents on a regional basis the kind of new institutional structure we need to cultivate on a global basis. To be sure, the EU sets limits on national sovereignty that did not exist before. Those limits, however, make possible new opportunities for cooperation that benefit the countries involved to a degree scarcely imaginable when they were willing to look after only their own individual interests. In the short term and in some specific areas, the interests of one country may not be well served by such cooperation, but in the long term the benefits will vastly outweigh the drawbacks. Without the support of a public educated in the wisdom of creating new institutions of authority to open up new frontiers of human freedom, we have no hope of making progress.

\section{CONCLUSION}

We now live in a multipolar world where the West no longer dominates and where the future survival of our species depends on our ability to live in reasonable harmony with cultures very different from our own and each other. We must now expand the scope of our national motto e pluribus unum to the entire world in such a way as to develop global institutions that preserve our diversity (our freedom) while fostering a new sense of common purpose (through authority). Potential leaders like China and Russia must be brought into the family of nations as cooperative partners in addressing the great issues facing the world as a whole.

What are the educational implications of this readjustment of the relationship between freedom and authority? Freedom exists within limits, within community. Democratic community is precisely that, a community, a context in which the individual is part of a whole. The purpose of education 
would therefore be, in part, to prepare students for participation in this whole. Pedagogically this means that the wholesale commitment to specialization in our divisions of knowledge must be balanced by a curricular focus on connections between specialized disciplines, connections between the learning that takes place in the classroom with the world of everyday experience, and connections between rights and responsibilities not only in a democracy but also in a world of interacting cultures and environments.

Our legitimate focus on rights must be balanced by a deeper understanding-fostered through our educational institutions - that rights do not exist in a vacuum but in a larger context of moral responsibility. Indeed, our intellectual and practical challenge is to call our society back to a consideration of the whole, not just the political, economic, social, or moral aspect of life, but all of them together. Freedom, to have any meaning at all, has to have an "outside frame of reference" (Brand, 1999, pp. 24-25). We have much to learn from older cultures (many of which the West formerly sought to dominate), but whose wisdom we now desperately need. They have developed philosophies of sustainability that rest upon a respect for the wholeness of life, which we have lost in our mechanistic view of the world.

We have to see our students, moreover, as whole persons, and we have to embark on a new campaign to engage all the principal American institutions-business, the media, the courts, government-in a new level of commitment to education. The schools cannot do it themselves. Once again, we need to look at the whole of American society and not confine our attention only to those professionally responsible for education. If we cannot break out of our mechanistic compartmentalization of education and make connections with American society as a whole, then we are doomed to repeat our endless cycle of reform, failure, and recrimination that seem to characterize every new wave of educational innovation in the past few decades.

If my study of world history has taught me anything, it is that human societies are most successful when their leading institutions of authority foster freedom by reinforcing certain basic values and behaviors. Unfortunately, our leading institutions do not always appear to reinforce the basic values and behaviors of our educational institutions, but too often actively undermine them by adopting a narrow interpretation of freedom as the removal of all constraints. That understanding leads to a view of the individual child as little more than a self-indulgent creature whose primary purpose in life is to produce and consume. A society that does not treat its children with the respect and dignity they deserve-as ends in themselves and not as a means to a productive economy - and does not teach its children that authority is the guardian of freedom and not its enemy, is in danger of eating its seed grain. 


\section{REFERENCES}

Brand, S. (1999). The clock of the long now: Time and responsibility. New York: Basic Books.

Burke, E. (1803). Letter to a member of the French Assembly. In The works of the Right Honourable Edmund Burke (Vol. 6, pp. 1-68). London: F. and C. Rivington.

Carson, R. (1962). Silent spring. Boston: Houghton Mifflin.

Dewey, J. (1899). The school and society. Chicago: University of Chicago Press.

Emmott, B. (1999, September 11). Freedom's journey: A survey of the twentieth century. The Economist, pp. 6-44.

Fagan, B. M. (1995). People of the earth: An introduction to world prehistory. New York: HarperCollins.

Goodlad, J. I. (1979). What schools are for: Bloomington, IN: Phi Delta Kappa Educational Foundation.

Goodlad, J. I. (1997). In praise of education. New York: Teachers College Press.

Hegel, G. W. F. (1956). The philosophy of history (J. Sibree, Trans.). New York: Dover.

Hucker, C. O. (1975). China's imperial past: An introduction to Chinese history and culture. Stanford, CA: Stanford University Press.

Keylor, W. E. (1996). The twentieth-century world: An international history. New York: Oxford University Press.

Mill, J. S. (1961). The essential works of John Stuart Mill. New York: Bantam.

Patterson, O. (1991). Freedom (Vol. 1). New York: Basic Books.

Postman, N. (1995). The end of education. New York: Alfred A. Knopf.

Smith, A. (1976). Theory of moral sentiments. New York: Oxford University Press.

Sobel, D. (1995). Longitude. New York: Penguin.

Stein, P. (1999). Roman law in European history. Cambridge, England: Cambridge University Press.

Treadgold, D. M. (1990). Freedom: A history. New York: University Press.

Weber, M. (1958). The Protestant ethic and the spirit of capitalism (T. Parsons, Trans.). New York: Scribner.

Wood, A. T. (2001). What does it mean to be human?: A new interpretation of freedom in world history. New York: Peter Lang.

Alan Wood is a professor in the department of interdisciplinary arts and sciences at the University of Washington, Bothell. Correspondence concerning this article should be addressed to Dr. Alan Wood, awood@u.washington.edu. 
Copyright of Catholic Education: A Journal of Inquiry \& Practice is the property of Catholic Education: A Journal of Inquiry \& Practice and its content may not be copied or emailed to multiple sites or posted to a listserv without the copyright holder's express written permission. However, user's may print, download, or email articles for individual use. 